\title{
E-waste Management in East African Community
}

\author{
Edgar Napoleon Asiimwe \\ edgar-napoleon.asiimweh081@student.oru.se \\ Supervisor \\ Prof. Grönlund Åke \\ Swedish Business School \\ Örebro University, Sweden
}

\begin{abstract}
The usefulness of Information and Communications Technologies (ICTs) has led to an overwhelming elastic demand for electronics most especially computing devices such as mobile phones and computers. Individuals and government institutions worldwide are adopting ICTs at a fast pace. Widespread consumption has resulted into huge amounts of Waste of Electrical and Electronic Equipment (WEEE) or e-waste generated from non-usable or old electronics. E-waste contains chemical elements that have adverse effects on the environment and human health.
\end{abstract}

Using semi-structured interviews and literature review, this study investigated the conceived role of East African Community (EAC) governments i.e., Kenya, Uganda, Tanzania, Rwanda and Burundi in combating negative impact of e-waste and how their views and current actions compare to the current state of the art in e-waste management. The results show that EAC governments consider e-waste to be a serious emerging problem. Despite this awareness and attempts to mitigate the problem in some of the countries, there are currently no solid solutions. The study suggests practical solutions that are most applicable in resolving e-waste challenges in EAC.

Keywords: E-Waste, Electronic waste, E-Waste management, Green IT, East African Community

\subsection{Introduction}

Information and Communication Technologies (ICTs) play a significant role in areas of development such as health (Kleine \& Unwin, 2009), education (Hayford \& Lynch, 2003), et cetera. However, ICTs are expensive to acquire and maintain. Difficulty in acquiring ICT 
materials such as hardware and software in developing regions has led to consumption of second hand products and software piracy. Some of the second hand products that are extremely old are commonly referred to as e-waste (Schluep, et al., 2008). Besides affordability factors, Nnorom \& Odjango (2007) suggest that e-waste is "internally generated or imported illegally as used goods in an attempt to bridge the so-called digital divide". Economically, urbanization and the growing demand for consumer goods in different regions of the world have increased the demand and supply of electronic products (Babu et al., 2007). This will lead to increased volume of e-waste. For example Robinson (2009) shows that computers, mobile telephones and television sets will contribute 9.8 million tons in e-waste stream by 2015 . These figures indicate that there will be a rise of 4.2 million in e-waste stream from 2010 to 2015 resulting from only computers, mobile telephones and television sets. A study by Greenpeace in 2008 estimated that, $25 \%$ and $20 \%$ of the e-waste is recycled safely in Europe and USA (Greenpeace, 2008). It also shows that China and India which have the biggest population in the world have large informal recycling sectors. For example $99 \%$ of India's e-waste goes to informal recycling sectors. This indicates that biggest portion of e-waste generated worldwide is not properly recycled.

It is clear that some of the discarded electronic gadgets contain highly toxic materials (Liu, 2009). Toxic materials can cause devastating health problems, for example cancer. In addition, e-waste pollutes the environment. Therefore poorly disposed ICT products such as computer hardware pose health threats to society. As the number of ICT users grows, e-waste will increasingly become an environmental/health hazard. Apart from the direct problems, this will also discredit ICT as a tool for development especially in poor regions. In relation to the above background, drastic measures are required to prevent e-waste from escalation.

\subsection{Objective of the study}

The objective of this study is to investigate the conceived role and actions of governments in EAC towards control of e-waste. The research questions are, (1) How do East African Community governments conceive their role in combating negative impact of e-waste? and (2) How do their views and current actions compare to the current state of the art in e-waste management? The overall contribution is to assess to what extent governments' actions are practical, sustainable and concur with the current state of the art in e-waste management. The 
study also suggests efficient and effective solutions based on other studies and practices in other countries.

\subsection{E-waste: definitions, history and contemporary discourse}

E-waste also known as 'Waste of Electrical and Electronic Equipment (WEEE)' or 'Electronic waste' is defined in various ways by different researchers. Davis \& Heart (2008) and ewasteguide (2009) define e-waste as obsolete, end-of-life or discarded appliances that use electricity. On the other hand, Peralta \& Fontanos (2005) define e-waste as "electronic products that no longer satisfy the needs of the initial purchaser". The term e-waste encompasses computers and their peripherals, consumer electronics, fridges, etc. that have been disposed off by firsthand users. However, the term is also used generically to describe all waste containing electrically powered components which are valuable, but hazardous and may require special handling and recycling methods.

Some definitions of e-waste reflect divergent but significant meanings. Secondhand products (some which are imported by developing countries) that are fully functional are regarded as ewaste because they (products) can no longer serve the needs of the original purchaser. The nature of some of these used e-products may not suit such definitions. For example a consumer can buy a product $B$ before their previously bought product $A$ is obsolete i.e., it has been used for a month when its end-of-life time is 3 years. The consumer's action could result from luxurious needs or product preferences e.g. new technology features appearing in a new version of the product. Disposing of product $A$ should not qualify it to be "e-waste" if it will be used by a secondary user at any time in its life time. Accordingly, we refine the above definitions to refer to e-waste as: electronic equipment that are considered to be hazardous and do not, in their functional state, serve any purpose to any intending user unless the equipment has been refurbished.

The e-waste concept came to light as far back as in 1970s and 1980s following environmental degradation that resulted from hazardous waste imported to developing countries (Shinkuma \& Huong, 2009). In reaction to hazardous waste importation, the Basel Convention on the control of transboundary movements of hazardous wastes and their disposal was instituted in 1992 to control the situation. Since then many countries have become members of the convention. 
Although "the Basel Convention does not regulate secondhand items and some e-waste scrap" (Shinkuma \& Huong, 2009), it has played a role in banning exportation of obsolete products and engineering waste solutions. For example its theme in 2006 was: "creating innovative solutions for the environmentally sound management of electronic waste" (Buenker, 2007).

E-waste phenomenon continues to flourish due to rapid adoption and use of ICTs which has contributed to increase in e-waste stream. E-waste is said to be one of the fastest growing waste streams (Cairns, 2005); growing at a rate of $3-5 \%$ per annum i.e., approximately three times faster than an ordinary municipal solid waste (Davis \& Heart, 2008). Increase in e-waste stream has attracted the attention of many governments, individuals and researchers due to its impact on the environment and human health.

In Europe, the EU implemented two directives i.e., Directive 2002/96/EC on WEEE and Directive 2002/95/EC on the restriction of the use of certain hazardous substances in electrical and electronic equipment (RoHS) (Peralta \& Fontanos, 2005). The directives enforce an extended producer responsibility system and encourage reuse, recycling and recovery, and minimizing the environmental impact of e-waste (Schmidt, 2005; Wen et al., 2006; Dwivedy \& Mittal, 2009). In addition, EU uses the concept of QWERTY/EE (Quotes for environmentally Weighted Recyclability and Eco-Efficiency) to improve or enable environmental performance of end-of-life products (Huisman \& Stevels, 2004). The QWERTY/EE strategies include determining: (1) weight based recycling and recovery targets, (2) restriction on hazardous substances, (3) treatment rules for recyclers, (4) minimum collection amounts, and (5) outlet rules for recyclers.

Other countries such as USA, Japan and china have also amended laws for e-waste management. In China, regulations that specifically deal with e-waste are in implementation. For example, the Management Measures for the Prevention of Pollution from Electronic Products regulation that aims at prohibiting the environmentally adverse processing of e-waste and reducing utilization of hazardous and toxic substances in electronic appliances (Xianbing et al., 2006).

Besides regulations, researchers have suggested various strategies of mitigating e-waste problems and solutions that lead to DfE (Design for Environment) or Green IT. Some of the suggested 
strategies include methods and models for predicting the flow of e-waste and assessing environmental impact of ICTs. It is argued in Shinkuma \& Huong (2009) that a traceability system for tracking/tracing e-waste information is required. Therefore models like Material Flow Analysis (MFA); a method applied to support the material and substance flow management in the waste (Streicher-porte et al., 2005) is required for e-waste mitigation. Wang \& Chou (2009) has also studied user behavior and willingness to recycle. All these developments have emerged drastically due to urgent needs for green environment and Green IT.

\subsection{About East Africa Community}

East African Community comprise of five countries. These countries include: Uganda, Kenya, Tanzania, Rwanda and Burundi. There is tremendous development in terms of technology and use of ICTs in EAC. For example mobile markets in this region are amongst the most liberalized on the continent where Kenya, Tanzania and Uganda are on top with about 10 million subscribers (ITU, 2009). The UN global e-government on Telecommunication infrastructure index and its components shows that there has been an improvement in use of ICTs in the region (UNPAN, 2010). Table 1 below shows statistics extracted from the United Nations Industrial Development Organization (UNPAN) surveys of 2010 and 2003 on internet, mobile phone and personal computer use (UNPAN, 2010 \& UNPAN, 2003).

Table 1. ICT use in EAC year 2010 and 2003*

\begin{tabular}{|c|c|c|c|c|c|c|}
\hline Country & \multicolumn{2}{|c|}{$\begin{array}{c}\text { Estimated Internet users } \\
\text { (in \%) }\end{array}$} & \multicolumn{2}{|c|}{$\begin{array}{l}\text { Mobile phone users } \\
\text { (in \%) }\end{array}$} & \multicolumn{2}{|c|}{$\begin{array}{l}\text { Personal computers } \\
\text { (in \%) }\end{array}$} \\
\hline Year & 2010 & 2003 & 2010 & 2003 & 2010 & 2003 \\
\hline Uganda & 7.90 & 0.2518 & 27.02 & 1.59 & 1.69 & 0.29 \\
\hline Kenya & 8.67 & 1.5978 & 41.88 & 4.15 & 1.37 & 0.56 \\
\hline Tanzania & 1.22 & 0.2977 & 30.62 & 1.27 & 0.91 & 0.36 \\
\hline Rwanda & 3.09 & 0.2516 & 13.61 & 1.1 & 0.30 & 0 \\
\hline Burundi & 0.81 & 0.0875 & 5.95 & 0.45 & 0.85 & 0 \\
\hline
\end{tabular}

* Figures in the table are converted to percentages.

Estimates were based on 1000 inhabitants and 100 inhabitants for years 2003 and 2010 respectively. The table shows figures which are converted to percentages. The difference in the number of telecom users from 2003 to 2010 is significant. The number of ICT users is expected 
to increase further after constructing broadband networks. This implies that there will be a rise in the e-waste stream.

In summary of all the above, ICTs have raised concerns related to health and environmental degradation thus "ICT development without an eye on Environmental Protection is not sustainable" (Tedre et al, 2009). Governments need to strengthen their role in environmental management and preservation. This study investigated the conceived role of EAC governments in combating e-waste. The rest of this paper presents the study method, results, discussion on findings, conclusions and limitations.

\subsection{Method}

This study used qualitative methods i.e., semi-structured interviews that primarily answered the first research question and literature review on electronic waste which primarily answered the second research question.

\subsection{Paper search, selection and review process}

For literature review, Google scholar and ELIN@Örebro-an Electronic Library Information Navigator at Örebro University were used to search for relevant articles from the web. E-waste, electronic waste, e-waste management, Green IT and East Africa Community were used (individually and in combination) as keywords in the search process that yielded 36 articles. Snowball technique was used to extract extra seven articles to make a total of 43 articles. In snowball method, references or bibliographies of cited articles are examined and used to obtain more papers. All selected articles are published since 2000 onwards.

\subsection{Interviews}

In addition to literature review, telephone and face-to-face semi-structured interviews were used for respondents in Tanzania and respondents in the rest of the countries respectively. E-waste data for developing countries is hardly available (Robinson, 2009). To prevent this setback from hindering the study, another method i.e., interviews was required. Meeting and interviewing officials in charge of issues related to e-waste and environmental management led to more tangible information especially undocumented and documented information that is not available on the web. In each country, two government officials from public sector organizations were 
interviewed. The selection of respondents was based on recommendations made by embassies and ministries for each country. Requests for officials working on e-waste were submitted to embassies in Sweden for Kenya and Tanzania and to ministries in charge of ICT and environment for Uganda, Rwanda and Burundi. The embassy of Burundi in Switzerland also helped in identifying the ministries mentioned above. In reply to the requests, contacts of specific people were provided. The interview questions focused on the issues below:

a. Awareness of the problem

b. Governments' initiatives for e-waste management, when and why were initiatives started.

c. Legislation

d. Current and future e-waste management strategies

e. Collaboration between government and private sector organizations in efforts to mitigate e-waste problems

f. Participation in environment conventions.

Five countries that formulate EAC, i.e., Uganda, Kenya, Tanzania, Rwanda and Burundi were taken as case study. The region is at risk of e-waste due to tremendous ICT reforms. This was the basis for the scope choice. In addition, the five countries have joined a regional federation thus reforms in one of the five countries can easily span to the rest.

There are many categories of e-waste. This study and its research instruments focus on the third among the ten categories listed in the EU directive on WEEE i.e., information technology and telecommunications equipment (labeled as ICT) (Streicher-porte et al., 2005; Widmer et al., 2005). The figure below shows the list of e-waste categories according to the EU WEEE directive. The third category is highlighted.

\begin{tabular}{lll}
\hline No. & Category & Label \\
\hline 1 & Large household appliances & Large HH \\
2 & Small household appliances & Small HH \\
3 & IT and telecommunications equipment & ICT \\
4 & Consumer equipment & CE \\
5 & Lighting equipment & Lighting \\
6 & Electrical and electronic tools (with the exception of large-scale & E \& E tools \\
& stationary industrial tools) & \\
7 & Toys, leisure and sports equipment & Toys \\
8 & Medical devices (with the exception of all implanted and infected products) & Medical equipment \\
9 & Monitoring and control instruments & M \& C \\
10 & Automatic dispensers & Dispensers \\
\hline
\end{tabular}

Figure 1. EU e-waste categories. Source: Widmer et al. (2005) 
Interviews were guided by a checklist that contained contemporary ideas discussed in e-waste literature. Although most of the models used in e-waste literature focus on e-waste data tracking and analysis, there are concepts which promote Green IT. The study followed some of the concepts of Electronic Product Environmental Assessment Tool (EPEAT), Basel Convention and EU e-waste directives (appendix B) to formulate interview questions and conduct the interviews.

\subsection{Results}

\subsection{Kenya}

Kenya's ICT industry is growing fast. Respondents stated that the rate of ICT acquisition specifically computers and mobiles is increasing. Most ICT products come from EU countries such as Britain, Asian countries such as China and Malaysia and USA. Generally ICT imports are new and old products are discouraged. However, there is a considerable portion of refurbished and old products brought in country through various channels such as NGO donations to institutions like schools. The primary reason for importing refurbished and old products is that people prefer cheap goods.

Respondents revealed that the country lacks a regulatory framework for e-waste management and that in the past; Kenya has not had a recycling policy on electronics. This is mentioned in Mureithi et al., 2008 that, in Kenya, "There are currently no legislation governing e-waste". Public Procurement Oversight Authority (PPOA) which oversees the procurement process in public sector is said to have not seriously considered end-of-life effects of products procured. One of the respondents suggested adjusting procurement policies by formulating environmental sound policies.

There are environmental regulations which are not specifically designed for e-waste. These include the waste management regulations of 2006 enforced by NEMA-the institution that implements all policies relating to the environment. These laws help in controlling generation, handling, transportation, storage, or disposal of waste that threatens public health, the environment or natural resources. There is also an ICT policy instituted by Ministry of Information and Communications (MoIC) in 2006. The policy demands electronics dealers to 
demonstrate their readiness to minimize the effects of their infrastructure on the environment in order to get their licenses renewed.

In addition, Kenya has a strategic plan (2006-2010) that aims at creating "an enabling environment through policy, legal and regulatory reforms" (Waema \& Mureithi, 2008). Implemented by Ministry of Environment and Natural Resources (MENR), the plan describes hazardous waste and pollutants. The environment awareness is high although sensitization is not specifically done on e-waste; one of the respondents stated that the government is planning to have guidelines for e-waste.

In a cause to fight against hazardous waste, Kenya is a signatory to numerous multilateral environmental agreements. Respondents mentioned some of these agreements as: (1) Basel convention on the control of Transboundary movements of hazardous wastes and their disposal; (2) Bamako conversion on the Ban of the imports into Africa and the control of trans-boundary movement of hazardous wastes into Africa; (3) Nairobi convention which provides a mechanism for regional (East Africa) cooperation, coordination and collaborative actions on solving pollution problems of the coastal and marine environment; (4) Stockholm convention on Persistent Organic Pollutants (POPs) and (5) Rotterdam convention on the Prior Informed Consent Procedure for Certain Hazardous Chemicals and Pesticides in International Trade. Respondents also highlighted the usefulness of such agreements i.e., promotion of mechanisms and infrastructure needs for greener environments, controlling and providing guidelines for cross boarder movements of hazardous components.

On the question of public-private sector partnerships, it was stressed by respondents that the government does not want to engage in business. However much there is a need to have facilities for recycling and re-use, such facilities have to be run by the private sector organizations. For example in 2008 the National Environment Management Authority (NEMA) signed a memorandum of understanding with an NGO i.e., CFSK (Computer for Schools Kenya) which set up a recycling plant. The move was one of the government's deliberate efforts to work on ewaste. NEMA also supports other non-governmental and private sector organizations that deal with waste management such as Practical Action, and Kenya National Cleaner Production Centre38 (KNCPC). It is clear that the government is willing to collaborate with private sector 
investors to control e-waste. Their contribution is to setup regulations, sensitize citizens and give economic incentives such as tax rebates if need be.

\subsection{Uganda}

In Uganda ICT use is increasing. Respondents stated that the trend of ICT adoption and use rises every year. Most imports are new while others are refurbished; in some cases consumers regard refurbished computers as "brand new". However, one of the respondents revealed that some of the imports are too old for use and that refurbishing is a common term used to mask old products. Using an example of old computers that were confiscated by NEMA, the respondent recited that importing republished products "is importing a problem". Moreover, there are no mechanisms to determine and prevent transfer of products from one place to another that are left with less time to their end-of-life.

USA, EU states such as UK and Asian countries i.e., China, Japan and Singapore, etc. were mentioned as sources for imports. Dell and HP are the giant computer brands. Mobile phones are mostly from Asia. In 2007, customs records indicated a total of 29,000 computer imports where 25,000 were new and 4,000 were second-hand (Wasswa \& Schluep, 2008). The figure below shows growth in the number of computer users as well as increase in the number of imported old computers in Uganda.
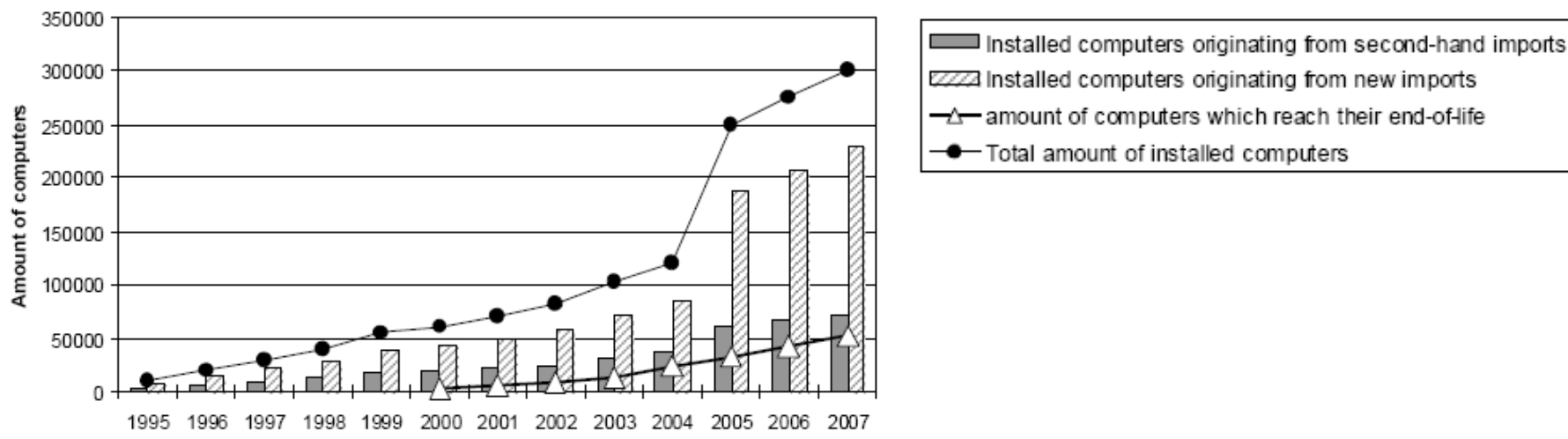

Figure 1: Growth in the number of users and increase in usage of old computers. Source: Wasswa \& Schluep (2008) 
Regarding e-waste management, the government acknowledges e-waste as a serious problem. In June 2009 a regulation that strictly burns importation of used electronics was passed and came into implementation beginning January 2010. The aim of this policy is to protect the environment (Bbumba, 2009) and "to encourage manufacturers to do the work from Uganda". Currently, there is no policy on recycling or any specific policy for e-waste. The country uses existing generic national environment policies for example the national environment acts of 1995 and 1999 that address solid waste issues (Wasswa \& Schluep, 2008; Schluep et al., 2008), and the waste and hazardous waste management regulations of 2000. These regulations are meant for providing sustainable management of the environment, help in monitoring and implementation of standards, and regulate management of all waste for instance solid wastes and hazardous wastes including: sorting, disposing, internal movement, transportation, packaging, labeling, trans-boundary movement, notification procedures and environmental impact assessment. One of the respondents stated that the ICT ministry will come up with a policy for e-waste later this year.

In efforts to make ICTs affordable, the government put tax wavers on brand new computers. The government also has interests in refurbishing and re-use; refurbished goods are considerably cheaper than brand new goods. In 2007, ICT ministry took an initiative with a Non Governmental Organization (NGO) - UNIDO to promote the use of ICTs among SMEs (MOICT, 2010). In 2006 UNIDO had partnered with Microsoft to make secondary PCs available to SMEs (Small and Medium Enterprises) in developing countries in a safe and sustainable way and intended "to support the establishment of local sustainable e-waste recycling facilities" (Wasswa \& Schluep, 2008). This would benefit the government if it collaborates with UNIDO. One of the responds also mentioned that the government is in the process of developing a disposal centre which should be up by 2011. At the moment only plastics and a few metallic materials are recovered. This is done by private sector companies.

Private sector organizations are steps a head of government in dealing with e-waste. Due to challenges involved in recycling, the government is interested in supporting and partnering with private sector organizations that are working on the issue. It is a national policy that the government should partner with private sector organizations and it facilitates this, through UIA 
(Uganda Investment Authority) which handles investments. The government's contribution includes giving tax waivers and formulating sound policies.

Regarding environmental agreements, Uganda is a signatory to Rotterdam, the Basel, the Stockholm conventions, the London Guidelines for the Exchange of Information on Chemicals in International Trade of 1987, the world charter for nature of 1982, the Montreal Protocol on substances that deplete the ozone layer of 1987, the Strategic Approach to International Chemicals Management (SAICM)-a policy framework that promotes chemical safety around the world, etc. Respondents stated that conventions play a big role in environmental campaigns.

\subsection{Rwanda}

Rwanda's ICT industry is also growing fast. "All schools and public institutions have computers". Exact statistics on Information and Communication Technology (ICT) use are currently not available but mobile phone subscriptions are high. A survey on ICT use is to be conducted in May 2010 among all stakeholders. Respondents recalled that there is huge importation of ICT products due to infrastructure building. Moreover, with government initiatives such as "one laptop per child" the number of users is expected to rise.

Respondents categorized ICT imports as Brand new, refurbished and old. Brand new imports constitute a large share because the government recently "stopped importation of old ICT equipment". Respondents also revealed that although warranties are provided to users, there are some poor quality imports especially mobile handsets. Some donations which are mostly taken to schools are also too old for use for example the first shipment of computers from Sweden to the national University of Rwanda; "all computers were old which rendered other shipments to be sent back".

Imports are from China, Dubai, Europe and Japan, etc with China emerging as the leading bulk exporter. Imports from Asia are cheap for example some used computers cost $\$ 80-\$ 100$; these are the most preferred because they are affordable. 
Regarding recycling, Rwanda has no plan, no recycling policy and no solutions for e-waste. Banning of old electronics is done "without law which is very difficult". The government is still analyzing the situation and is in the process of formulating e-waste policy. "The policy will empower the public sector, and help in setting up facilities, regulating and giving licenses". So far one of the deliverables of this initiative is a draft on Terms of Reference (ToR) for assessment of e-waste status and trend. The ToR is to be completed in April 2010. "E-waste is now a priority. By the end of June the whole study will be finished and by the end of the year all tools required will be in place" and guidelines will be provided. Respondents also noted that having a recycling plant would be the most viable solution to e-waste but "it takes long because it requires resources". Therefore it is the current study that will give a vision on how to solve the problem.

Respondents acknowledged the role of multilateral environment agreements in controlling ewaste at international level. Rwanda is a signatory to many agreements. Respondents mentioned some of them which are listed in the environment organic law of Rwanda (Grandslacs, 2010) for example: Stockholm convention, Rotterdam convention, Basel convention, Montreal convention, the Kyoto Protocol to the Framework Convention on Climate Change, etc. respondents confirmed that conventions are necessary because they guide countries in developing their own policies and regulations.

Regarding private-public partnership, one respondent stressed that: "the government does not want to go into business". A committee mandated to work on e-waste suggested that: "the government should invest in a recycling plant" or support, in anyway, an investor interested in recycling business. However, no decision has been made about the suggestion. Respondents noted that the best strategy for dealing with e-waste is "taking a multi-stakeholder approach" where the government, people, NGOs and the private sector organizations are involved. Therefore partnering with the private sector is a positive strategy.

In summary respondents expressed concern that, given the physical geography of the country i.e., the landscape, components containing hazardous materials can flow in rivers and valleys to all parts of the country. Therefore with continuous ICT developments, e-waste problems will become severe thus drastic measures are required. On the other hand, one of the respondents 
stated that although "e-waste is a problem; it is a resource and an opportunity for creating revenue". This calls promoting recycling and re-use.

\subsection{Tanzania}

Tanzania is going through an ICT transformation thus the country is susceptible to benefits and drawbacks of ICTs. The rate of acquiring computers and mobile phones is "high but not very high". Most ICT imports are from China, Japan, Malaysia, and UK. These imports were described as new, refurbished or old. The government encourages new imports but old imports are also available in large quantity. "There is a problem of controlling quality" and "the government is fighting fake products". Respondents stated that the government considers e-waste to be a problem and stressed the need for drastic measures such as formal sector recycling rather than informal sector recycling. "Recycling is done by informal sector which has its own business motives". The government is also considering tracking and registering all devices being imported which can help to promote quality.

Regarding e-waste management planning, the government has no specific solutions for e-waste. The government's role is to provide guidelines, make the public aware of problems and solutions, formulate and implement domestic laws. Awareness of ICT environmental issues is almost nonexistent in Tanzania and the country's current legal and regulatory framework is deficient (Tedre et al., 2009). The country has general national environmental regulations such as the NEP (National Environmental Policy) of 1997 that addresses management of hazardous waste, i.e., how to properly dispose-off waste in an environmental friendly manner.

On issues of public-private sector partnership, the government works closely with the private sector "especially on development aspects" and it prefers private investors to run businesses due to limited resources. Private sector investors are given incentives such as "tax waivers and land allocation". The government also seeks collaboration with NGOs. For example one respondent mentioned that it is working closely with UNIDO on refurbishing and e-waste management issues. Tanzania is also an active member in many conventions. Respondents mentioned some of these i.e., the Basel and Bamako conventions. They stated that conventions are important in giving directions on how to formulate domestic laws. 
All in all, the government needs to strengthen its role in formulating environmentally sound policies, supporting the private sector and educating the public. A Green IT course was introduced at university of Tumaini that aims at promoting awareness of ICT environmental issues for instance the legal frameworks instituted by the country and learning how to make ewaste profitable (Tedre et al., 2009). Such initiatives should be promoted.

\subsection{Burundi}

Burundi like other EAC states is experiencing increase in the number of computer users. However, the rate of adoption and acquisition of ICTs is not as high as that of Kenya, Uganda, Tanzania and Rwanda. “Computers are few but many people buy mobile phones".

Respondents noted that a big ratio of imports is from Asia specifically China and The United Arab Emirates. The rest come from EU countries such as France and Belgium. The imports are new, old or refurbished. Respondents mentioned that "Most people prefer cheap products" for example those from China. In most cases, cheap ones are either old or refurbished. Despite this consumer preference, brand new ICTs take the biggest share on the market.

E-waste awareness in Burundi is non-existent. One of the respondents stated that "it has never been an issue in Burundi and e-waste lies mostly in houses not in streets". The government has no plan for e-waste management and there is no recycling policy either. Although some environment management officials in the government are aware of the problem, "no one has brought the issue to regulators and the public".

On an international level, the country is a signatory to Bamako, Basel, Stockholm, and Rotterdam conventions, etc. one of the respondents stated that it is important to be a signatory to environmental agreements although there is not much action done to enforce such agreements at a national level. Benefits of conventions mentioned by respondents included policy formulation on hazardous waste and financial support. All in all the "government is open on any positive initiatives" including private sector reforms but the set back is lack of resources and initiators. Ewaste effects are disastrous and respondents commended that there should not be a delay in handling the problem. 


\subsection{Discussion}

\subsection{Discussion on findings}

Results show a correlation with Streicher-porte's argument that "most developing countries lack e-waste regulations" (Streicher-porte, et al. 2005). All five countries lack concrete regulations for e-waste yet the number of ICT users is continuously growing where the growth is high in all countries except Burundi. In all countries, products consumed are brand new, refurbished or old. China is the leading exporter of cheap ICT products most especially mobile phones and their accessories. These cheap products are of low quality thus their lifetime is short.

All governments encourage use of brand new products. On the other hand people prefer cheap goods and thus old and refurbished products are also used. In countries such as Uganda and Rwanda where old products are restricted, old products are imported under the umbrella of NGOs or through black markets.

In all countries, governments are aware of e-waste as a serious problem although the awareness in Burundi is not high. Rwanda, Kenya, Tanzania and Uganda have already realized the need to study the problem and find solutions. The fact that governments do not want to engage in business, partnering with private sector organizations is a positive strategy towards building robust infrastructure for handling e-waste. The considerable financial constraints of ICT users in developing regions, strategies such as total ban of old imports are not reasonable. Governments should devise ways of refurbishing old products and lowering prices of brand new ICT products in Uganda where taxes on brand new computers were waived.

The five countries have signed environmental agreements at international level. This is an indicator of efforts to control trans-boarder movement of hazardous waste materials. However, international regulations have less impact without national regulations. E-waste policies and guidelines are therefore required at national level. E-waste policies should enforce a take back policy or Extended Producer Responsibility (EPR) system. According to Kahhat et al. (2008) and Khetriwal et al. (2009), EPR strategies make manufacturers entirely responsible for collection, recycling and final disposal of products. In EAC, EPR strategies are implemented by a few 
organizations for example Microsoft through UNIDO (United Nations Industrial Development Organization) initiatives. Most manufacturers do not implement a take back system for their products.

Besides formulating regulations for hindering the problem, governments should make users (citizens) aware of how to safely dispose of waste. People in developing regions have perceived use value of old materials; old garbage especially electronics is not disposed of for a long time. For example in Burundi "most of the waste lies in homes not on streets". There is also a need for waste disposal centers because keeping waste in homes is attributed to lack of waste disposal centers for certain waste.

E-waste has many benefits despite its disadvantages. Through proper recycling there are opportunities such as employment and waste bi-products. E-waste can generate revenue for example "on average, informal e-scrap recyclers in Nairobi can earn US\$ 3 a day, which is above the global poverty alleviation target of US\$ 1" (Schluep, 2009). In 2007 in China, 88.843 million tons of recyclable waste were traded and recycled at a total value of 34.85 billion USD (Mo et al., 2009). Governments should promote exploration of all these opportunities.

Mitigating e-waste problems requires understanding the flow of materials through which waste is generated. There are many models used to track and analyze the flow of waste materials and there are tools used to procure long lasting, environment friendly products. Because there is no sufficient data on the flow of waste in EAC member states, governments should use models such as the MFA model (appendix B) to investigate the flow of hazardous materials. It is equally important for electronic governments to promote and use "green" ICTs thus tools such as EPEAT (appendix B) should also be used when ICT procurement. 


\subsection{Summary of findings}

Table 2 below, summaries the findings of the study for all countries i.e., Kenya, Uganda,

Rwanda, Burundi and Tanzania. The findings are summarized according to interview themes.

Table 2: Summary of findings according to interview themes

\begin{tabular}{|c|c|c|c|c|c|}
\hline \multirow{3}{*}{$\begin{array}{l}\text { Interview themes } \\
\text { Problem awareness - } \\
\text { Views on e-waste } \\
\text { management planning }\end{array}$} & \multicolumn{5}{|c|}{ Comments on each country } \\
\hline & \multicolumn{2}{|c|}{$\begin{array}{ll}\text { Kenya } & \text { Uganda }\end{array}$} & \multirow[b]{2}{*}{$\begin{array}{l}\text { Rwanda } \\
\text { The government is } \\
\text { aware of the } \\
\text { problem and they } \\
\text { intend to come up } \\
\text { with guidelines } \\
\text { and other } \\
\text { necessary tools to } \\
\text { control the } \\
\text { problem by the } \\
\text { end of } 2010 \text {. }\end{array}$} & Burundi & \multirow[b]{2}{*}{$\begin{array}{l}\text { Tanzania } \\
\text { Tanzania is aware } \\
\text { of the problem but } \\
\text { apart from national } \\
\text { environment } \\
\text { regulations there is } \\
\text { no solution or plan }\end{array}$} \\
\hline & $\begin{array}{l}\text { The problem } \\
\text { has been } \\
\text { acknowledged } \\
\text { and the } \\
\text { government is } \\
\text { in the process of } \\
\text { formulating a } \\
\text { specific policy } \\
\text { for e-waste }\end{array}$ & $\begin{array}{l}\text { The government is } \\
\text { aware of the problem } \\
\text { and intends to } \\
\text { formulate policies } \\
\text { and guidelines by the } \\
\text { end of } 2010\end{array}$ & & $\begin{array}{l}\text { The awareness } \\
\text { is low and the } \\
\text { government has } \\
\text { no plans }\end{array}$ & \\
\hline $\begin{array}{l}\text { Current and future } \\
\text { initiatives and } \\
\text { strategies for e-waste }\end{array}$ & $\begin{array}{l}\text { The government } \\
\text { discourages old } \\
\text { imports and is } \\
\text { working with } \\
\text { NGOs to } \\
\text { introduce } \\
\text { recycling and a } \\
\text { take back policy }\end{array}$ & $\begin{array}{l}\text { The government } \\
\text { banned importation } \\
\text { of old electronics, } \\
\text { waived taxes on } \\
\text { computers and is } \\
\text { working closely with } \\
\text { NGOs to introduce a } \\
\text { take back system as } \\
\text { well as recycling }\end{array}$ & $\begin{array}{l}\text { Controls } \\
\text { importation of old } \\
\text { ICTs but with no } \\
\text { laws }\end{array}$ & $\begin{array}{l}\text { No plans, } \\
\text { initiatives and } \\
\text { strategies }\end{array}$ & $\begin{array}{l}\text { Old imports are } \\
\text { discouraged and } \\
\text { the government is } \\
\text { working closely } \\
\text { with NGOs to } \\
\text { introduce a take } \\
\text { back system as } \\
\text { well as recycling }\end{array}$ \\
\hline $\begin{array}{l}\text { Importation/acquisition } \\
\text { trend/rate of ICTs } \\
\text { (computers and mobile } \\
\text { phones) }\end{array}$ & Very high & Very high & Very high & Average & High \\
\hline $\begin{array}{l}\text { Source of these ICT } \\
\text { mentioned }\end{array}$ & $\begin{array}{l}\text { Britain, Asian, } \\
\text { China, } \\
\text { Malaysia, USA }\end{array}$ & $\begin{array}{l}\text { USA, UK, Asian, } \\
\text { China, Japan and } \\
\text { Singapore }\end{array}$ & $\begin{array}{l}\text { China, UAE, } \\
\text { Europe and Japan }\end{array}$ & $\begin{array}{l}\text { China, Japan, } \\
\text { Malaysia, and } \\
\text { UK }\end{array}$ & $\begin{array}{l}\text { China, } \\
\text { France } \\
\text { Belgium }\end{array}$ \\
\hline $\begin{array}{l}\text { Description of ICT } \\
\text { imports }\end{array}$ & \multicolumn{5}{|c|}{ Brand new, Refurbished and Old } \\
\hline $\begin{array}{l}\text { Recycling policy on } \\
\text { ICTs }\end{array}$ & \multicolumn{5}{|c|}{$\begin{array}{l}\text { No recycling policy on ICTs. Each country has general national environment policies for control and } \\
\text { proper disposal of waste. }\end{array}$} \\
\hline $\begin{array}{l}\text { Multilateral } \\
\text { Environmental } \\
\text { Agreements } \\
\end{array}$ & \multicolumn{5}{|c|}{$\begin{array}{l}\text { All countries are signatories to more than four international conventions and protocols that tackle } \\
\text { environmental issues for example Basel convention, Bamako convention, Stockholm convention, } \\
\text { Montreal convention, etc. }\end{array}$} \\
\hline $\begin{array}{l}\text { Comments on } \\
\text { signatories }\end{array}$ & \multicolumn{5}{|c|}{$\begin{array}{l}\text { Conventions guide regulators in formulating national laws and help in controlling transfer of hazardous } \\
\text { waste across nations. Conventions also avail opportunities such as financial support to build } \\
\text { infrastructures. }\end{array}$} \\
\hline $\begin{array}{l}\text { Public-private sector } \\
\text { partnership }\end{array}$ & \multicolumn{5}{|c|}{$\begin{array}{l}\text { Due to challenges for example limited resources such as finances, governments do not want to engage } \\
\text { in business and prefer to support the private sector through giving incentives, formulating sound } \\
\text { policies, etc. }\end{array}$} \\
\hline
\end{tabular}




\subsection{Conclusion and Limitations}

This study investigated the conceived role of five EAC governments in combating electronic waste and compared the results to current state of the art in e-waste management worldwide. The study also re-defines e-waste to portray the divergent definitions in e-waste literature. Results show that some countries such as Kenya, Uganda, Rwanda and Tanzania are aware of the e-waste implications although there is not much work done to mitigate the problem. All countries are signatories to multilateral environmental agreements but these agreements have less impact on overcoming the problem at a national level. Below are the answers to the research questions:

(1) How do East African Community governments conceive their role in combating negative impact of e-waste? Results show that governments play the following roles:

1. Serve as regulators and problem investigators

2. Educate and sensitize citizens through environmental campaigns

3. Support private sector organizations and NGOs through incentives such as tax rebates and land allocation where company operations can be carried out.

4. Promote practices for greener environments

5. Collaborate with other countries through conventions to control transboundery movements of hazardous material and environmental pollution

(2) How do their views and current actions compare to the current state of the art in e-waste management? In comparison to the current discourse on e-waste management in different countries, below are observations on governments' actions:

1. Governments are following international agreements to control movement of hazardous materials to and from the country. This is done in many countries.

2. Rwanda began controlling importation of old electronics with laws. This is not a formal practice elsewhere for example in Europe.

3. Some countries use tracking systems to trace the flow of e-waste. This not the case in EAC states.

4. EAC states use general environment regulation unlike other countries such as EU states which have specific policies for e-waste. 
5. Countries such as Kenya and Uganda can recycle some of the old materials. Although the work is by private sector organizations, these organizations are supported by the government which is common elsewhere.

In relation to the above practices we recommend governments to:

a) First, study the flow of e-waste using tracing systems with a purpose of identifying the source and distribution channels;

b) Implement systems for controlling imports;

c) Use proper ICT procurement tools such as EPEAT to ease the assessment and identification of the best products that are environment friendly when procuring;

d) Formulate and implement strict e-waste policies for cracking down illegal imports and;

e) Build recycling infrastructure and support local investors in the recycling industry.

In addition, e-waste has economic benefits and one way of obtaining these benefits is through proper recycling which requires building recycling infrastructure. Since governments are not interested in business, private sectors should be partnered to build the infrastructure. There is an urgent need to hinder the problem due to the fast growing number of ICT users. This calls for drastic measures.

Private sector organizations are at frontline in solving E-Waste problems in EAC states especially in Kenya and Uganda. We suggest that future studies should look at the role of private sector organizations. In addition, future studies should endeavor to review data on imports from customs agencies to extract exact statistics on the flow of ICT in the five countries. 


\subsection{References}

Babu, B. R., Parande, A. K., \& Basha, C., A. (2007). Electrical and electronic waste: a global environmental problem. Waste Management \& Research, 25(4), 307-318

Buenker M. (2007). The New Frontier: E-waste. Environmental Policy and Law, 37(1), 22-24

Cairns, C., N. (2005). E-waste and the consumer: improving options to reduce, reuse and recycle. Proceedings of the IEEE International Symposium on Electronics and the Environment, pp. 237242

Davis, G., \& Heart, S. (2007). Electronic waste: The local government perspective in Queensland, Australia. Journal of Resources, Conservation and Recycling, 52(8-9), 1031-1039

Dwivedy, M., \& Mittal, R., K. (2009). Estimation of future outflows of e-waste in India. Waste Management, 30(3), 483-491

Peralta, G. L., \& Fontanos, P., M. (2006). E-waste issues and measures in the Philippines. Journal of Material Cycles and Waste Management, 8(1), 34-39

Ewasteguide (2009). e-Waste Definition. Retrieved 6 December, 2009, from Ewasteguide, Web site: http://ewasteguide.info/e_waste_definition

Grandslacs (2010). Organic Law $\mathrm{N}^{\circ}$ 04/2005 of 08/04/2005 Determining the modalities of protection, conservation and promotion of environment in Rwanda. Retrieved 21 March, 2010, from Grandslacs, web site: http://www.grandslacs.net/doc/4063.pdf

Greenpeace (2008). Switching on Green Electronics: E-waste- 'not in my backyard. Retrieved 20 March, 2010, from Greenpeace, web site:

http://www.greenpeace.org/raw/content/international/press/reports/Switching-on-Green-

Electronics.pdf

Hatton, J. (2009). Policy, Legal and Institutional Framework: Mozambique, Tanzania, Zanzibar \& Kenya: Summary. The Eastern African Marine Ecoregion, Retrieved 13 April, 2010, from EAME, web site: http://eame.wiomsa.org/pubs/EAMEJohnHattonPolicySummary.pdf

Hayford, L. C., \& Lynch, P. (2003). A Review of Good Practice in ICT and Special Educational Needs for Africa. Retrieved 18 March, 2010, from Imfundo, Web site:

http://imfundo.digitalbrain.com/imfundo/web/papers/SEN/SENPHASE1FINAL.pdf

Huisman, J., \& Stevels, A. (2004). Eco-efficient implementation of electronic waste policies in practice. Electronics and the Environment Conference Record for 2004 IEEE International Symposium, pp. 243-248.

ITU (2009). East Africa's Telecoms Competition Laboratory Spurs Fast Growth. Retrieved 28 Febuary, 2010, from ITU, Web site:http://www.itu.int/ITUD/ict/newslog/East+Africas+Telecoms+Competition+Laboratory+Spurs+Fast+Growth.aspx 
Kahhat, R., Kim, J., Xu, M., Allenby, B., \& Williams, E. (2008). Proposal for an e-waste management system for the United States. IEEE International Symposium on Electronics and the Environment Year, pp. 1-6

Kleine, D., \& Unwin, T. (2009). Technological Revolution, Evolution and New Dependencies: what's new about ict4d? Third World Quarterly, 30(5), 1045 - 1067

Liu, Q., Li, Q. K., Zhao, H., Li, G., \& Fan, Y. F. (2009). The global challenge of electronic waste management. Environmental science and pollution research international, 16(3), 248-249.

Mo, H., Wen, Z., \& Chen, J. (2009). China's recyclable resources recycling system and policy: A case study in Suzhou. Resources, Conservation and Recycling, 53(7), 409-419

MoICT (2010). Ministry of Information and communications Technology Uganda: District Business Information Center. Retrieved 26 March, 2010, from MoICT, Web site: http://www.ict.go.ug/index.php?option=com_content\&view=category\&id=25\&Itemid=93

Nnorom, I. C., \& Osibanjo, O. (2007). Overview of electronic waste (e-waste) management practices and legislations, and their poor applications in the developing countries. Journal of Resources, Conservation and Recycling, 52(6), 843-858.

Robinson, B., H. (2009). E-waste: An assessment of global production and environmental impacts. Science of the Total Environment, 408(2), 183-191

Schluep, M. (2009). E-waste management in Africa - Rising up the political agenda. Retrieved 28 Febuary, 2010, from ewasteguide, Web site: http://ewasteguide.info/Schluep_2009_RI

Schmidt, M. (2005). A production-theory-based framework for analysing recycling systems in the e-waste sector. Environmental Impact Assessment Review, 25(5), 505-524

Shinkuma, T., \& Huong, M., T., N. (2009). The flow of E-waste material in the Asian region and a reconsideration of international trade policies on E-waste. Environmental Impact Assessment, 29(1), 25-31

Steubing, B., Böni, H., Schluep, M., Silva, U., \& Ludwig, C. (2009) Assessing computer waste generation in Chile using material flow analysis. Waste Management 30(3), 473-482

Streicher-Porte, M., Widmer, R., Jain, A., Bader, H. P., Scheidegger, R., \& Kytzia, S. (2005). Key drivers of the e-waste recycling system: Assessing and modeling e-waste processing in the informal sector in Delhi. Environmental Impact Assessment, 25(5), 472-491

Tzonline (2009). National Environmental Policy of the united Republic of Tanzania. Retrieved 13 April, 2009, from Tanzania online, web site:

http://www.tzonline.org/pdf/nationalenvironmentalpolicy.pdf 
UNPAN (2010). Global E-Government Survey 2010. Retrieved 28 February, 2010, from UNPAD, Web site: http://www2.unpan.org/egovkb/global_reports/10report.htm

UNPAN (2003). Retrieved 28 February, 2010, from UNPAN, Web site: http://unpan1.un.org/intradoc/groups/public/documents/un/unpan016066.pdf

Wang, C., \& Chou, T. (2009). Personal Computer Waste Management Process in Taiwan via System Dynamics Perspective. International Conference on New Trends in Information and Service Science, pp. 1227-1230

Wasswa, J., \& Schluep, M. (2008). e-Waste Assessment in Uganda: A situational analysis of ewaste management and generation with special emphasis on personal computers. Retrieved 6 December, 2009, from Ewasteguide, web site:

http://ewasteguide.info/system/files/Wasswa_2008_UCPC-Empa.pdf

Wen, X., Li, J., Hao, L., Yin, F., Hu, L., Liu, H., \& Liu, Z. (2006). An Agenda to Move Forward $E$-waste Recycling and Challenges in China. Proceedings of IEEE International Symposium on Electronics and the Environment, pp. 315-320

Widmer, R., Oswald-Krapf, H., Sinha-Khetriwal, D., Schnellmann, M. \& Boni, H. (2005). Global perspectives on e-waste. Environmental Impact Assessment Review, 25(5), 436-458

Xianbing, L., Masaru, T., \& Yasuhiro, M. (2006). Electrical and electronic waste management in China: progress and the barriers to overcome. Journal of Waste Management \& Research, 24(1), 92-101. 


\section{Appendices}

\section{Appendix A: Interview Questions}

Subject description to the respondent: The trend of ICT use in your country shows that there is continuous growth in the number of users. It is therefore assumed that the country is facing/will face e-waste problems. E-waste describes electronic products such as mobile phone, computers that no longer serve their initial purpose (are old or faulty) and require proper disposal methods.

1. What is the importation/acquisition trend/rate of ICTs i.e., computers and mobile phones in your country?

2. What is the source of these ICT imports?

3. How do you describe these ICT imports?

4. How does the government consider e-waste?

5. What is the country's recycling policy on electronics specifically ICTs for the past 3 years?

6. What are the government's considerations for e-waste management planning?

7. Mention the multilateral environmental agreements your country is a signatory of?

8. What do you say about multilateral environmental agreements in regard to e-waste control?

9. What is the governments stand on public-private sector partnership in dealing with ewaste problems?

10. Any other general or specific comments (final remarks) you would like to make? 


\section{Appendix B: Interview questions Checklist (Green IT strategies and model, and legislation)}

The concepts below are widely discussed and used in e-waste literature. In order to identify any developments related to these concepts for example how e-waste is managed in East Africa Community, we used these concepts as our guidelines (anonymous to the respondent) during the interviews.

\section{EPEAT (Electronic Product Environmental Assessment Tool)}

EPEAT is an environmental tool designed to help public and private sector institutions in evaluating, comparing and selecting (while buying and procuring) ICTs i.e., desktop computers, laptops and monitors that hold environmental friendly attributes. EPEAT principles (product select principles) include:

- Promotion of toxics reduction or removal

- Promotion of materials efficiency

- Promotion of energy efficiency

- Promotion of extended product life and sustainable end-of-life management

- Promotion of environmentally sound manufacturing

The above principles help in reducing e-waste. For example products last longer and may not cause environmental or health problems. Guiding question: Are there any e-waste assessment tools in East Africa Community?

\section{Basel and Bamako Conventions}

The Basel Convention on Control of Transboundary Movements of Hazardous Wastes and Their Disposal bans exportation of hazardous waste across countries especially from developed to developing countries. It requires exporters to declare any of such products and to seek approval from the government of an importing country (Shinkuma \& Huong, 2009). In 2006 the convention adopted new guidelines on environmentally sound management of used and end-oflife mobile phones (Buenker, 2007). The Bamako Convention also bans importation of hazardous waste into Africa and controls trans-boundary movement of hazardous wastes into the continent. Since EAC states are signatories to these conventions and many others, we intended to find out how they are implementing the objectives of any convention to fight against e-waste. 


\section{EU e-waste regulations}

European Union (EU) has WEEE directives for example 2002/96/EC and 2002/95/EC directive which restrict use of hazardous substances in electrical and electronic equipment. According to Wen et al. (2006), RoHS (Restriction on the use of certain Hazardous Substances in electrical and electronic equipment) directives have many advantages including:

- Technology innovation enhancement

- Promotion of green design

- Environmental protection

- Leads to sustainable development

The directives also enforce a system of extended producer responsibility (EPR) where manufacturers take care of e-waste product. Guiding question: Is there any of such directives in East Africa Community?

\section{E-waste data collection and flow analysis models}

To be able to track e-waste flow in a country, methods and systems have to be used to collect and analyze data based on the flow of purchased and disposed electronics. There are many models suggested researchers for example the Material Flow Analysis (MFA) (Streicher-porte et al., 2005). We intended to find out whether there are any methods (new models or those in practice) used to track e-waste information). Guiding question: Are there any methods used to track ewaste information in East Africa Community? 